\title{
The Political Metaphor in the Mirror Worlds: Narrative Structure and Identity in The Man in the High Castle
}

\author{
Yanping Gao
}

\begin{abstract}
Science fiction always embodies the author's understanding and introspection of human history, present and future in varying degrees, so do the works of Philip K. Dick, particularly The Man in the High Castle. In this book, he overheads the history and narrates a different story from the real. Also, he embeds the Mise en abyme in the virtual story in the book and shows a third space free from the historical reality and fiction. The parallel operation of the triple worlds constitutes the narrative structure of the text. The high castle world in the book reverses the history and provides a background and living environment for the characters in the novel, and the dominantly national model in this world is the political-ethnic power hierarchy which, to a large extent, influences the subject's construction and identity. However, these triple worlds contain a common political metaphor, that is to say: the reproduction and imagination of utopia of the history or future -always contain a potential danger of simulation of the Metacolonization.
\end{abstract}

Index Terms-The Man in the High Castle, mise en abyme, outsider, metacolonization, political metaphor.

\section{INTRODUCTION}

Science fiction has invariably been an important part of the history of literature. In recent years, there is a boom on the creation and criticism of science fiction, which provides a practical field for people to explore and think about history and future of human beings, especially at the political level.

For Dick, the fabulous world with utopian nature in science fiction does not exist and will never come. Human history has repeatedly proved that utopia itself is of a paradoxical nature. Utopia always has a close relationship with hegemonism, in other words, utopia itself is the product of dialectics between good and evil. In his work The Man in the High Castle (2003) [1], he rewrites the results of World War II and discusses the plight of human politics. Any victorious countries seem to inevitably repeat American-style hegemonic politics, some are radical and other may be more moderate, but the essence is the same and human needs to be wary of any forms of hegemony.

\section{Mise en Abyme: The TRIPLE Worlds of PARALLel UNIVERSE}

In the field of physics, a parallel universe is used to stand

Manuscript received January 1, 2017; revised February 7, 2018.

Yanping Gao is with the Chinese Language and Literature Department in the school of Humanities and Social Science in East China Normal University, Shanghai, China (e-mail: yanpinggaoecnu@foxmail.com). for a set of states that contains a multidimensional universe which can accommodate a variety of possible things and is always open to infinite possibilities. This term has much similarity to the literary space, in other words, the literary space is a good place for parallel universe, especially science fiction.

\section{A. Narrative Structure and Constitution of the World}

When readers read The Man in the High Castle, the real history of the real world they live is the necessary reference, that is, real history is one of the worlds, which is called "real world"; the history of the world in high castle which is over headed by Dick is the second world, which is called "the world of high castle". It is noteworthy that, in The Man in the High Castle, Dick embeds a narrative Mise en abyme, that is, embedding a book in the book. The book is The Grasshopper Lies Heavy which is a novel that many characters in The Man in the High Castle can read and can be seen as a fictional world called "Grasshopper world" That is the text which presented by the Third Space. Here, I use the term Third Space of Soja [2] to describe Grasshopper world partly because Grasshopper world has many differentiates from the real and fictional history. On the other hand, the Grasshopper world is locally integrated with another two worlds. These two characteristics of Grasshopper world, to a certain extent, make it fit the theoretical demands of the Third Space. It can be said that the "real world", "high castle world" and "Grasshopper world" together constitute the narrative structure of the novel.

Firstly, the narrative structure which consists of the triple spaces relies on several major historical events. In the real world, American president Roosevelt has survived before and after World War II; in the high castle world, Giuseppe Zangara kills Roosevelt, changing the direction of history; in the grasshopper world, Hawthorne Abendsen believes that Roosevelt will be a very strong president who cannot be assassinated in Miami. Similarly, in the real world, the Pearl Harbor incident led to great losses to the United States and the Pacific War broke out accordingly; in the high castle world, Japan in the Pearl Harbor incident defeated the Pacific fleet, and received the German assistance; in the grasshopper world, Abenderson believes that President Tugwell has ordered all ships to be open to the sea, so the US warships are intact. In the case of Roosevelt and Pearl Harbor, the real world is not exactly the same as the grasshopper world. In the high castle world, Dick envisions the assassination of Roosevelt, which has changed the 
history of the whole world.

\section{B. Possible Events and Conception of Time of Dick}

Quantum theory in physics is based and operates on the potential possibility, that is all possible events, no matter how strange or ridiculous, will have a certain probability of occurrence. In the high castle world, Roosevelt is assassinated, which, to a certain extent, changes the history of the world. In terms of the real world, though Roosevelt is assassinated in history, the assassination is not life-threatening at all. Throughout the history of the human, past events in this period have been completed, settled down, and combined with the construction of historians, and finally become a complete chain of narrative history. Furthermore, in the grasshopper world, Roosevelt is assassinated, the United States and Britain defeats axis powers, the Soviet Union is divided, with the end not the same as that in the real world. So what we call the real world is perhaps one form of the possible world, such as Bloch's explanation of the category of possibility:

“人不仅是在历史中形成了自身的现实, 而且是至今 尚未形成的万有的实际可能性; 物质也同样是潜在于自 身怀抱并通过过程而出离物质的一切的世界可能性。”

Man is not only in the history of the formation of their own reality, but also the practical possibilities of all which have not yet formed ; materials are also potential in their own arms and exist in all the possibilities of the world through the process and out of the materials. [3]

Whether it is human individual, or the process of the world's history, all can be seen as a presentation of "possibility" of Bloch.

These triple worlds imply Dick's concept of time: the past time is not closed or completed, it is precisely open; the so-called current is rapidly becoming history; and the coming future just retreats with a rapid speed at which we can catch a glimpse of our human history through this decay and retreat. Our human history comes from a variety of possible events, the appearance of any of which would break the chain of history and will cause unexpected results.

\section{OUtSIDER: THE WAY OF HuMAN EXISTENCE UNDER THE POLITICAL-NATIONAL MODEL}

Although Dick overheads history in The Man in the High Castle, he neither spends a lot of inks to describe the world he builds, nor pays much more attention to the high castle world where is full of people's daily life and experiences. In other words, history is only the background of people's activities.

\section{A. Polyphonic Narrative with Multi-Focus}

Darko Suvin, a contemporary critic of science fiction, points out that The Man in the High Castle presents as a multifaceted polyphonic narrative [4]. Obviously, The Man in the High Castle, is divided into 15 chapters, and the narrative of each chapter is basically completed by the different characters in the book in an alternative way. For example, the first chapter of the book is narrated by two main characters: Robert Childan and Frank Flink. The former is a boss of an American crafts company and the latter is a newly unemployed Jewish worker. The narrative is dominated by the third-person perspective, but sometimes the narrator will speak standing on the position of certain character in the book. For example, in the eyes of blacks and ordinary Americans, Robert Childan apparently lives a decent life. He, who often deals with the Japanese and the Germans, sometimes triumphantly feels satisfied for the matter, but in dealing with the Japanese he is trembling with fear, and always thinks too much. Frankly speaking, his spirit is in an extreme tension. While when he meets blacks and ordinary Americans, he stands high above the masses, and even tries to exploit and laugh at the workers, thus his ugly and hypocritical face is revealed. Obviously, we cannot define him with a single character and he is kind of complex in personality. It is not difficult to find that this multifocal polyphonic narrative puts each character in a specific context, so that the reader is most likely to be close to the thought of the every character, consequently both the victims and the destroyers will get the sympathy and understanding from readers.

The characters of the book live in a world which is overheaded by Dick, it is precise that this inverted historical situation will put ordinary people of the vanquished country into a kind of existential scene. A large number of storylines in the book focuses on the daily life details of the characters, such as diet, work, meetings, transactions, reading, divination, etc., so the plots of story precisely lead us to such a situation of how to survive in the absurd historical reality under the political-national model as the outsider and other.

\section{B. Human's Survival Situation under the Political - National Model}

Obviously, in The Man in the High Castle, the German Nazis occupy the top of the political structure and are always with the greatest power, as shown in Table I:

TABLE I: THE POWER STRUCTURE IN THE High CASTLE WORLD

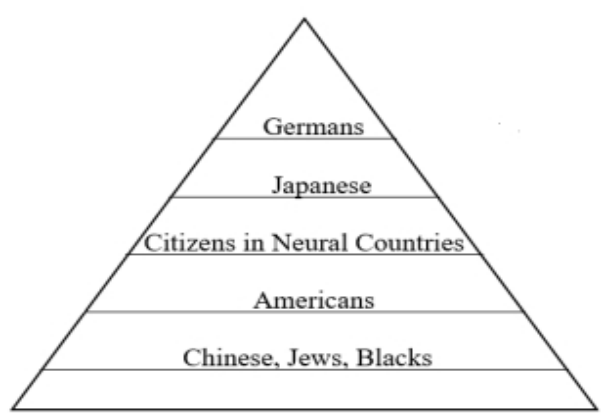

After Baumann's death, there is a bipolar struggle in Germany. With Dr. Goebbels acting as a prime minister, while Heidrich is the other pole, their fraction and clash around the dandelion plan and interstellar colonial struggle is on the verge of breaking out. Japan, as a victorious nation, 
is on the second layer of the overall political structure. Compared with the aggressive and brutal attitudes and strategies of Germany, Japanese politics is more cunning and round. Neutral states basically enjoy the same political status as Japan. Americans are in the third floor of the political structure and the Chinese, Jews and blacks are at the bottom. Every member of the class is labeled. The whole castle world is actually in such a political-ethnic model and operates under the power, and the cross-border in any layer will inevitably lead to the most ruthless repression of the top floor structure. The right of the top controller is to require the absolute obedience from people in other levels.

Under this absurd historical background, the identity of the characters is a matter of concern. Speaking of identity, it is necessary to involve the matter of subject.

In Lacan's view, the subject in psychoanalysis is precisely the composition of a discourse. Psychoanalyst in this discourse plays a role in the presence of the "who has not yet done anything to intervene"[5], and then the patient has already been launched with the degree of dialogue, i.e. the presence of a potential dialogue which does not need any real conversations between each other through voice. In The Man in the High Castle, Flink appeared in a completely chaotic state in the first chapter of book:

“在弗兰克·弗林克位于赫耶斯街的房间，他正躺着不 知道怎样起床。阳光透过百叶窗照在一堆掉在地板上的 衣裳, 还有他的眼镜。他要踩上这些东西? 还是走旁边 的路去洗澡间好? 他想。爬起来还是滚过去。他的头很 疼, 但他并不发愁。他决心再不回头看。什么时间了? 钟在梳妆台上, 11 点 30 分! 真可悲, 但他仍旧躺着。”

In his room on Hayes Street, Frank Frink lay in bed wondering how to get up. Sun glared past the blind onto the heap of clothes that had fallen to the floor. His glasses, too. Would he step on them? Try to get to bathroom by other route, he thought. Crawl or roll. His head ached but he did not feel sad. Never look back, he decided. Time? The clock on the dresser. Eleven-thirty! Good grief. But still he lay. [1]

The narrator describes the emotional state of Flink with the third-person perspective, where a rising act of getting up arouses a series of questions in Flink's mind.

Obviously, he does not forget how to get up, neither does he know what to do after getting up, how to face the fact that he has been dismissed, and how to live his own life after unemployment. At this moment, Flink's self-consciousness vanishes, leading to his own behavior out of control, and then the spirit and the flesh splits. Then, Flink falls into the idea of a future action, how to go to the Labor Defense Committee to check his work records, how to defend himself, but the idea ends in the failure of the defense. Experiencing a series of future fantasies failure, he keeps the state of lying on the bed. Here, Flink's future fantasy lacks a person who can have a dialogue with him, as Labor Committee is under the Japanese control. Then he falls into the other plan, he wants to escape from here and flies to entirely unfamiliar places, but finds that it is almost impossible. There's nowhere to run from the future. Flinks then drops into the past memories of himself and thinks of years of wartime, recalling a Russian who pressed the poor and was finally punished by the Japanese. At this time, Flink seems becoming confident to the Japanese government and is no longer confused about his own future. Once upon a time, Flinks had no confidence in the cohesion of the Pacific Alliance, and thought that it was a clear lie and an empty propaganda. But at the moment, imagining the good behavior of Japanese in past, his confused heart is confirmed. Russian and Japanese in the memory of Flink became people who could have a potential dialogue with him, which completed Flink's construction and confirmation of the self-subject. So, he completed the action at the moment to get up. The presence of subject is closely related to the time-off, which means that when subject starts to forget time, he/she will begin to focus on his /her own things and take action. Immediately, the news in the radio brought Flink back to the real world. By using the "Book of Changes" for divination, Flink gets a variable hexagram, so he once again falls into memories of his wife, through memories, Flink finds a complete and continuous self, positioning himself as a divorced man as well as an unemployed worker.

In psychology, when a desire which is similar to the Gestalt psychological schema is not met, the subject will transfer to the symbolic satisfaction. In addition to Flink, other characters either fall into the illusion of the future, or fall into memorizing the past when they face hard situation. In fact, whether it is fantasy or memory, the escape from reality is actually a traumatic performance, and the existence of trauma presents that desire is difficult to meet. In the political-national reality, they are always outsiders of their own countries, always facing a pervasive power control. A trauma of lack of identity can find comfort only in the past memories, and fantasy in grasshopper world heals this trauma to some extents, but the existence of trauma has gradually become a kind of colonial self. Without getting rid of the trauma, it will seriously limit the ability of the characters to act at last.

\section{The Polttical Metaphor: Utopian MirRor Under METACOLONIZATION}

\section{A. Daily Life and Utopian Impulse}

Roland Barth points out in the "Sade, Fourier, Lolita" that "utopian sign is the daily life," [6] Because in this real-life experience, the time of individual and collective is in a good consistency.

The activities of ordinary common public in the world of high castle are different from the daily life of people in the real world in the history overheaded by Dick. People, from Jews to American, from Japanese to Germans, are all living in the power structure under political-ethnic model. In other 
words, they are different from the way we treat life, and their utopian impulses are hidden in the individual's fantasy, just as what Bloch says about the "daydreaming". For example, Abenderson who lives in a high castle transfers his utopian impulse into a utopian conception through the literary creation, as Dick uses an open end, so it is uncertain that the war between Germany and Japan will be an opportunity to change utopia vision into a real plan.

Compared to the utopian form of daily life in the high castle world, the utopian impulses of Nazi Germany come from the ideological conflicts with many countries including Japan. In the view of the rulers of Germany, the world can only have one pole, thus Japanese, Jews, Americans, and Chinese all need to surrender to Germany. The surrender will be followed by the massacre movement, because they need pure German descent to occupy the world and other races are just grasshopper. Germany's dandelion plan is to exterminate Japan and its space plan is to carry out interstellar colonization, which can make us think about the present situation that we live, the so-called exploration launched in the Mars, and the moon and the universe is a kind of science under the banner of interstellar colonization. After the death of Prime Minister Bormann, there are several candidates. Despite of different characters, they are all fascinated by power and support the Nazis' brutal policies. The Utopian impulse and the utopian plan are carried out in an orderly manner, and the German emphasis on action is related with this manner.

\section{B. Political Metaphor and Metacolonization}

In the book, Dick seems to have a preference for the Japanese rule, because compared to Germany's brutal, crazy and mad policy, Japanese pays more attention to the combination of law and morality, but in fact, whether it is in the German occupied area, or Japanese occupied area, people of other races always need to disguise themselves and carefully cater to the rulers. In the world of grasshopper created by Abenderson, the United States and Britain win the victory, but the result is that they repeat the mistakes of Germany and Japan, as Flink says," We live in a world of insanity, Madman who holds the right "[1] In contrast to the political reality of today's society, these words seems to be wonderful irony and express a political metaphor. Again, as Baynes's thought on the way to Germany,

“即使戈贝尔博士被废黜, 它们仍然存在着, 党卫军、 纳粹党, 这些计划不是在东方就是在在其他什么地方进 行, 甚至在火星和金星上进行……我们没有一个我们喜 爱的理想世界。”

Even if Dr. Goebbels is deposed, they still exist, the SS, the Nazis, if these plans are not in the East,they are in other places, even on Mars and Venus on ... ... we do not have a favorite place of our ideal world .[1]

Baynes's remarks shatter all the imagination of utopia, and it seems that we have a potential dystopia to appear when we pursue the ideal world. But his words reveal that whether in the high castle world or not, the various utensils of the utopia which are envisioned or conceived is only a mirror, and it is a different manifestation of a single replica, and then, is the imagination of utopian has an original source of structure? Here, I am enlightened by the criticism of critic Cassie Carter on Dick's revelation, quoting his critical terminology -Metacolonization [7] for the analysis of the utopian image. In Carter's view, Metacolonization refers to a kind of original colonial ideology, a fixed idea behind the performance of the colonial phenomenon.

In the preceding article, I mentioned that the people in the high castle world live under a political-ethnic model, but characters in the novel and their actions are not entirely limited in this level of rights: the emotional entanglement between Juliana and Cinnadella give birth to the dialogue and emotion; and then to the United States, Childan is very humble and timid when discusses business with Japanese Tagomi and is attracted by Paul couple's elegant demeanor. He admires the Japanese way of domination, but privately ridicules them as "the yellow". Especially when Chidan finds that they have strong curiosity to the United States Crafts, Childan has his own old American pride and the deep contempt for the Japanese show. The most dramatic is that Childan tries to lure Paul's wife with the handicrafts which are made by Flinks. When this thing is perceived by Paul who shows disdain for the handicrafts of Childan, he even asks Paul to apologize to him, and Paul agrees. This thing that happened is completely out of the strict power structure, Childan's "deviant". Ironically, Childan is proud of his old American artwork, immersing in the fantasy of the old American dream, but in fact many American crafts he has sold are fakes. It can be seen that the Americans in the high castle world are actually colonized by their own romantic fantasies. Childan is satisfied with his career, and all his career is related to the old honor of the United States. He often blames the Japanese buyers who do not know what are in good quality, then he begins to gradually accept new things. But the United States still has nostalgia. Juliana and Flinks are also full of memories of the old American, the saddest thing is that they are immersed in this false fantasy to be satisfied. Interestingly, the Japanese people in the book think that the past history of the United States is very valuable and they are keen to collect these items, contributing to the cause of the hot of American crafts. But with the so-called American history being precisely adapted, constructed, imitated, the merchant Tamigo finally feels difficult to know which is the real history of the United States, and also hard to distinguish the good from the bad crafts in the end which can be seen from the dialogue between Tamigo and the mistress: the newspaper proves the value of the thing, not the object itself. In this view, it seems that when we talk about history, history itself is a utopia which needs to be constructed.

\section{Imitation: Utopian Mirror}

In the world of high castle, the Japanese wins the victory 
in World War II and brings "Book of Changes" to the people in the occupied area, so that they rely on the wisdom of the Eastern book to divine their own destiny. But the Japanese way of life and the aesthetic pursuit are totally Americanized. They speak English, despite of the poor pronunciation; they are dressed in a style of westernization, although these clothes do not match their stature; they also imitate the diet of Americans, though not skilled. They are fascinated by their legitimacy as a victory by imitating Americans.

In Paul's example, their life is a full-fledged American style and they imitate the traces of the Americans, including clothing, food, house, and transportation. In the view of postcolonial theorist Fanon, the imitation of the colonized sometimes plays a role of decolonialism [8], but in the high castle world, the situation is upside down, as the colonists' imitation of the life style of the colonized just reveals a shocking truth that Japan's colonization of the defeated country is only an illusion and an old American dream is the murderer of the colonization. The imitation is in a symbolic way to complete the pursuit of the American dream. The defeated country put all the material and spiritual pursuit on the American dream. The so-called oriental wisdom "Book of Changes" is disguised to play the role of ideological colonization, of which the function is to make the colonized lose the ability to resist and think.

It is evident from the beginning that the defeated people are colonized by their own fantasies, which is a life that had disappeared,. It seems that the Japanese people are the actors of the colonists, but in fact they imitate the dream of the United States, because the idea of their own still stays in the "Dao" and "Book of Changes", which may be one of their colonial style relying on which they can survive. Generally, the Japanese imitates the Americans. The story of the grasshopper world confirms the colonial truth of the American dream in the high castle world, and Dick envisions that the United States would treat the defeated country like Japan in the high castle, but it seems that the readers will be skeptical of such an idea, and doubt that he still has fantasy of American dream. For the sake of clarity, below Table II is drew according to the information provided in the book:

TABLE II: THE Symbolic Relationship BetWeEn Silver TRIANGLE AND AMERICAN DREAM

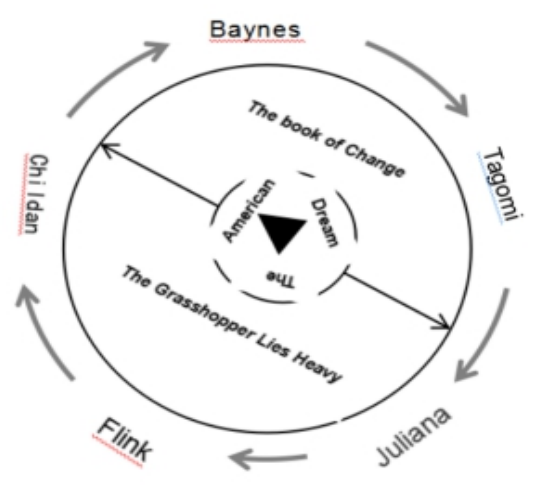

The American dream is located at the center circle of the whole circular structure, which is the product of violence and glory, war and freedom.
The glamorous surface of American dream infiltrates the control of right, and it is the traces of centralized control behind the heroism. The American dream itself deeply penetrates the fascist factor, in other words, there is an absolute close relationship between American dream and fascism. It is always trying to impose their ideal pursuit to others by the cruelest means. Then in this view, Germany and Japan in the high castle world are two components of the American dream, one is the totalitarian rule, one is the wisdom of the integration of oriental civilization, which always impacts the live way the characters .

It is important to note that the balance emphasized by the Japanese provided a hotbed of this political utopia. There is a wonderful symbol of the American dream which appears in the text, that is, Flink produces a handmade jewelry-a single small silver triangle. Tagomi catches in a crisis after the death of the German, he buys a silver triangle jewelry in Childan's handicrafts company. The fourth chapter of the novel spent a lot of inks to describe the silver triangle. Silver triangle has the most dirty, dark, cruel side, but also is a symbol of balance. It has the sun side as it is "the epitome of the world" [1].The American dream is such a structural existence which implies the dialect of good and evil, containing, free, democratic implication as well as violence and centralization. The silver triangle is the best symbol of the American dream and the structure of this power is characterized by its existence as invisible but self-running, which is similar to the metaphysical white mythology:

What is white mythology? It is metaphysics which has effaced in itself that fabulous scene which brought it into being, and which yet remains, active and stirring, inscribed in white ink, an invisible drawing covered over in the palimpsest. [9]

American dream is also a disguised white mythology. In the real world, the American dream has brought disaster to many countries and regions; in the high castle world, the American dream embodies as the fight between Germany and Japan, as well as the performance of the Japanese imitation of American; in the grasshopper world, the American dream flees the high Castle world' loft of power, openly walking into the public view. The triple world, in fact, is a mirror of the American dream, and it is a centralized doctrine behind it. Under the control of the American dream, Bloch's hope and love cannot save the world and only a few people can get their own salvation. Faith cannot be saved and it is a false to hope to get redemption in the centralized society. It is worth mentioning that Dick seems to have a right view of women saving the world, because there is no civilization without women, the book of female characters Juliana shoulder the task, not only have to outwit gestapo, but also risk her life to save the man in high castle.

The American dream plays a role of Metacolonization, which keeps a constant transformation and immerses into the ideology of nations. Ironically, the American dream is not only of America, because the United States itself is based on the value and practice of European settlers, so the American 
dream itself is an ironic structure. In other words, the colonists are also colonized by ideology and suffering the consequences.

\section{CONCLUSION}

Critic John Rieder thinks that "the structure of the novel's world can be understood as a manifold of hermeneutic codes generated in contradiction to and critical reflection upon a fundamental code of realist referentiality" [10] Rieder intends to affirm the critical value of the novel in The Man in High Castle. Yet this critical reflection does not occur in ethical value, especially the relationship of people, but ultimately points to a skepticism about the truth which, of course, has a close relationship with history. Rieder immediately points out:

One's cognition of reality cannot reliably guide ethics, and yet one's sense of the human nonetheless inevitably produces an ethically determined inter-pretation of reality. The concept of truth is thus impossible to establish, but also impossible not to produce [10].

Perhaps when we talk about the truth, it is not true or false, but a problem of language construction which requires the majority of people to recognize, and contextual reference is important here, so the truth is not true, it can only be relative. The same is that history itself is an utopia, fantasy may also be a reality in our life.

Referring to the narrative Mise en abyme in The Man in High Castle, as the existence of the third space, it is true that Mise en abyme fuses and traverses the reality and fiction which may theoretically be able to provide a relatively good way out for a possible world in mankind. However, in the third part of the analysis, it can be seen that this possible world may also be a colonial mirror image. It seems that from this point Soja and Homi Baba's Third Space theory itself is in danger of bankruptcy [11].

\section{REFERENCES}

[1] P. Dick, The Man in the High Castle, Trans. Cao Guochen. Nanjing: Jiangsu Education Press, 2003.

[2] A. Edward W Soja, Third Space: Journeys to Los Angeles and Other Real-And-Imagined Places, Trans Lu yang, etc. Shanghai:Shanghai Education Pressing House,1996.

[3] E. Bloch, The Principle of the Hope, Trans. Menghai, Shanghai, Yilin Press, 2002.

[4] D. Suvin, Positions and Presuppositions in Science Fiction, Trans Hao Lin, Li Qingtao, Cheng Jia. He Fei: Anhui Literature and Art Publishing House, 2011.

[5] J. Lacan, Complete Works of Lacan, Trans. Chu Xiaoquan. Shanghai: Sanlian Bookstore, 2001.

[6] R. Scholes, F. Jameson, and A. B Evans, etc., Criticism and Construction of Science Literature, Trans .Wang Fengzhen, Su Zhan, Li Guangyi , Anhui Literature and Art Publishing House 2011 edition.

[7] C. Carter, "The metacolonization of dick's 'The man in the high castle': Mimicry, parasitism, and Americanism in the PSA," Science Fiction Studies, vol. 22, no. 3, 1995.

[8] R. Young, White Mythologies: Writing History and the West, Trans. Zhao Xifang. Beijing: Peking University Press, 2014.

[9] J. Derrida, "White mythology: Metaphor in the text of philosophy," F. C. T. Moore, New Literary History, vol. 6, no. 1, 1974.

[10] J. Rieder, The Metafictive World of "The Man in the High Castle": Hermeneutics, Ethics and Political Ideology, Science Fiction Studies, 1988, vol. 15, no. 2.

[11] H. K. Bhabha, "The commitment to theory," New Formations, vol. 5, 1988.

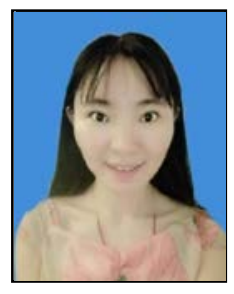

Yanping Gao was born in Yin Chuan of Ningxia province, China. She received her B.A. in Chinese language and literature at ZheJiang GongShang University in 2015. Currently, she is a graduate student of the Department of Chinese Language and Literature of School of Humanities and Social Science in East China Normal University in Shanghai. Her research interest includes English literature, literary theory, and cultural studies. 